LII Zakopane School of Physics, International Symposium Breaking Frontiers, Zakopane, Poland, May 22-27, 2017

\title{
Applications of Comet Assay for the Evaluation of Genotoxicity and DNA Repair Efficiency in Nanomaterials Research
}

\author{
A. PAneK ${ }^{a, *}$, M. BŁażeWicz ${ }^{b}$, A. FrącZEK-SzCZypta ${ }^{b}$, J. AdAmCZYK $^{a}$, \\ J. WiltowskA-ZubeR ${ }^{a}$ AND C. PALUszKIEWICZ ${ }^{a}$ \\ ${ }^{a}$ Institute of Nuclear Physics, Polish Academy of Sciences, PL-31342 Krakow, Poland \\ ${ }^{b}$ AGH University of Science and Technology, Faculty of Materials Science and Ceramics, PL-30059 Krakow, Poland
}

\begin{abstract}
The single cell gel electrophoresis method, known as comet assay, is a rapid and sensitive technique for testing novel chemicals and nanoparticles for genotoxicity, monitoring environmental contamination with genotoxins and human biomonitoring. In our studies we check the applicability of this method for the evaluation of biocompatibility of modified (MWNF) and non-modified multi-walled carbon nanotubes (MWNT) as well as potential genotoxicity of mercury(II) nitrate. The obtained results enabled us to conclude that the presence of $\mathrm{Hg}\left(\mathrm{NO}_{3}\right)_{2}(p<0.001)$ and MWNT $(p<0.04)$ cause a significantly higher level of DNA damage in comparison to functionalised nanomaterials MWNF. It was implied that for the three investigated agents only mercury significantly enhanced genotoxic effect of X-ray exposure $(p<0.001)$ and inhibition of radio-induced DNA damage repair. On the contrary, the presence of MWNF have no influence on cellular repair efficiencies, while incubation with MWNT causes apoptosis and consequently results in lack of attached cells. In conclusion, our results confirmed the genotoxicity of mercury and non-modified carbon nanotubes as well as the biocompatibility of modified nanotubes. Additionally, we proved the usefulness of comet method for the evaluation of genotoxicity and DNA repair under the influence of different compounds and nanomaterials.
\end{abstract}

DOI: $10.12693 /$ APhysPolA.133.280

PACS/topics: 87.53.-j, 87.85.jj, 87.14.gk

\section{Introduction}

The single cell gel electrophoresis (SCGE) method is a rapid and sensitive technique for assessment of DNA damage in individual cells [1-4]. This technique was developed in 1984 by Ostling and Johanson [5]. The comet assay measures the electrophoretic migration of relaxed or fragmented DNA in relation to the nuclei of cells immobilized onto an agarose gel. The distance and/or amount of DNA migration from the individual nuclei provide information about the number of strand breaks. This technique allows for the detection of DNA damages such as single-strand breaks, double strand breaks, alkali labile damage, incomplete excision repair sites, and DNA-DNA crosslinks. One of the main applications of this assay is testing novel chemicals and nanoparticles for genotoxicity, their interaction with another genotoxic agents and influence on cellular repair capability. This is the preliminary step towards investigation of their toxicity and biocompatibility $[6,7]$. For genotoxicity and DNA repair studies, two different types of materials were analyzed: non-modified and modified by oxide multi-walled carbon nanotubes (MWCNT) potentially designed to medical applications. Genotoxic mercury(II) nitrate $\left(\mathrm{Hg}\left(\mathrm{NO}_{3}\right)_{2}\right)$, as a positive control of the correct action of the above test, was used.

*corresponding author; e-mail: Agnieszka.Panek@ifj.edu.pl

\section{Materials and methods}

The pristine multi-walled carbon nanotubes were provided by NanoAmor USA. The MWCNTs diameters were in the range from 10 to $30 \mathrm{~nm}$, while their length was within the range of $1-2 \mu \mathrm{m}$. These nanotubes were also chemically oxidized in a mixture of concentrated $\mathrm{H}_{2} \mathrm{SO}_{4}$ and $\mathrm{HNO}_{3}$ acids (MWCNTF), according to the procedures described in detail elsewhere [8]. Before cells were exposed to the CNTs, both types of samples (MWCNTs, MWCNT-Fs) were immersed in PBS and dispersed for 2 min using a tip sonicator (Palmer Instruments, model: CP $130 \mathrm{~PB})$. Next, $20 \mu \mathrm{M}$ of $\mathrm{Hg}\left(\mathrm{NO}_{3}\right)_{2}$ or $38 \mu \mathrm{g} / \mathrm{ml}$ MWCNT dissolved in PBS was added to medium with cells for $1 \mathrm{~h}$.

In biocompatibility study, human lymphocytes and fibroblasts were used. The normal human skin fibroblasts (CCL-110) cell line (the American type culture collection, ATCC) was cultured in MEM medium supplemented with $20 \%$ FBS, $1 \%$ penicillin - streptomycin and $2 \mathrm{mM}$ L-glutamine. The cells were grown at the temperature of $37^{\circ} \mathrm{C}$ and $5 \% \mathrm{CO}_{2}$. Human lymphocytes were separated from blood using Histopaque separation medium (Sigma) following the manufacturer's procedure. The lymphocytes were frozen and thawed according to standard procedures [9].

\subsection{X-rays}

For this study there was selected dose of 1 Gy as a typically fractionated dose using in cancer therapy. Exposure of X-rays was carried out using a Philips MCN 323 machine at $250 \mathrm{kV}, 10 \mathrm{~mA}$. The dose rate given 
was $2 \mathrm{~Gy} / \mathrm{min}$. The fibroblasts line and lymphocytes were irradiated in the Petri dishes and the Eppendorf vials, respectively. After the exposure, all samples were transported to the laboratory. Then, cells intended for repair competence studies were suspended in incubation medium and transferred into an incubation chamber $\left(37^{\circ} \mathrm{C}\right.$ and $\left.5 \% \mathrm{CO}_{2}\right)$ for $24 \mathrm{~h}$ to allow cells to repair induced DNA damage. The rest of the irradiated cells immediately after exposure were transferred for SCGE assay procedure.

\subsection{Comet assay}

Detailed applied protocol of comet assay can be found in [9-11]. About 1000 cells (in $30 \mu \mathrm{l}$ ) have been embedded in agarose $(120 \mu \mathrm{l})$ on a microscope slide. The cells were then lysed for one hour in $2.5 \mathrm{M} \mathrm{NaCl}, 100 \mathrm{mM}$ EDTA, 1\% sodium sarcosinate, $100 \mathrm{mM}$ Tris, $10 \%$ DMSO and $1 \%$ Triton-X-100. The DNA was subjected to alkaline electrophoresis (1 mM EDTA; $300 \mathrm{mM} \mathrm{NaOH}$ ). The electrophoresis was carried out at $4{ }^{\circ} \mathrm{C}$ with parameters $30 \mathrm{~V}, 300 \mathrm{~mA}, 0.7 \mathrm{~V} / \mathrm{cm}, 30 \mathrm{~min}$. After staining cells with an appropriate dye (ethidium bromide $17 \mathrm{mg} / \mathrm{ml}$ ), cellular DNA was visualized using a microscope. In this study Olympus BX 50 epifluorescence microscope equipped with $100 \mathrm{~W}$ mercuric lamp, excitation filter $515-560 \mathrm{~nm}$, barrier filter from $590 \mathrm{~nm}$, and a CCD camera have been used. For the analysis of DNA in the comets, the Komet 3.0 software (Kinetic Imaging Co., Liverpool, UK) was applied. To estimate the extent of DNA damage, the comet tail moment parameter (TM) was used. TM is valued from percentage of DNA in a comet tail multiplied by a length of the comet tail. Tail moment incorporates a measure of both the smallest detectable size of migrating DNA (reflected in the comet tail length) and the number of relaxed/broken pieces (represented by the intensity of DNA in the tail). For each chemical compound, two experiments were performed, each with two independent repetitions.

\section{Statistics}

Two independent experimental replicates were performed for each aliquot. 200 cells were analysed for each data point ( 2 slides per each dose, 100 cells analysed from each slide). The statistical analysis was performed using $t$-Student test and ANOVA analysis from MS Excel software.

\section{Studies of genotoxicity and influence on DNA damage repair}

The genotoxicity assessment methods should be characterized by a list of criteria: sensitivity, rapidity, simplicity, and ability to assess damage in both proliferating as well as non-proliferating cells. In this study, we explore the versatility of the comet assay in the evaluation of the DNA damage level in different cellular models: cell lines (fibroblasts) and human blood lymphocytes. The scheme of the genotoxicity and DNA damage repair studies is shown in Fig. 1. The cell studies were divided into six categories. One of them was used to study the basic level of DNA damage (control). Second part of cells was incubated with nanomaterials or chemicals for $1 \mathrm{~h}$. Table I shows the cell response for the presence of the $\mathrm{Hg}\left(\mathrm{NO}_{3}\right)_{2}$ or biomaterials detected by comet assay. Results obtained for tail moment parameter indicate the significantly higher level of DNA damage in the presence of $\mathrm{Hg}\left(\mathrm{NO}_{3}\right)_{2}(p<0.001)$ and MWNT $(p<0.04)$, but for functionalized nanomaterials MWNF is similar as for control. The results obtained for mercury are consistent with previous studies conducted by Williams et al. [12] for mercuric acetate and Cantoni and Costa [13] for $\mathrm{HgCl}_{2}$, who state that mercury ions induce DNA single stand breaks. Another example concerns genotoxicity of non-functionalized multi-walled carbon nanotubes [14].

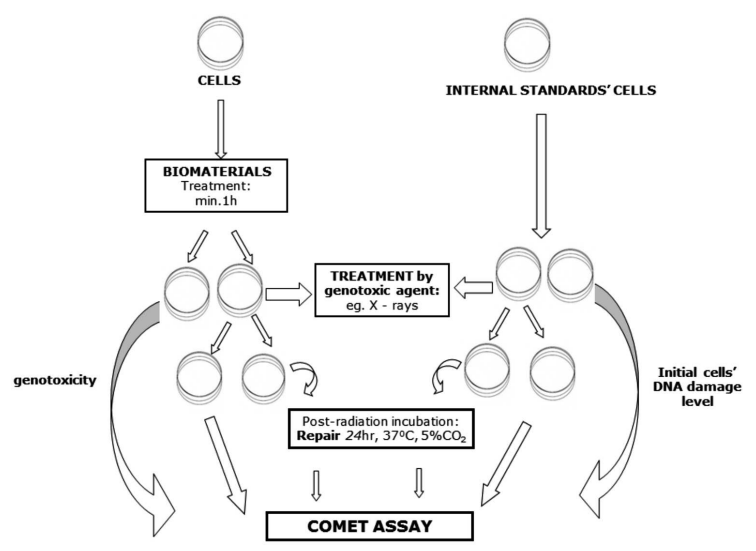

Fig. 1. Scheme of the procedure used in studies of genotoxicity, susceptibility to the induction of DNA damage and the capacity to repair it.

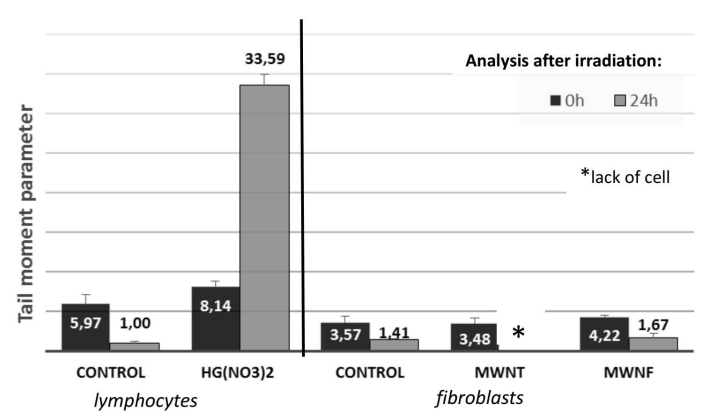

Fig. 2. Influence of $\mathrm{Hg}\left(\mathrm{NO}_{3}\right)_{2}$ and nanomaterials on radio-induced DNA damage repair.

The remaining four parts of cells were used to study the level of DNA damage after the challenging dose of X-rays. The first two parts (one without and one after chemical treatment) were used to study interaction of ionizing radiation with investigated materials. Radiation induced DNA damage levels in cells pre-treated with $20 \mu \mathrm{M}$ of $\mathrm{Hg}$ ions or $38 \mu \mathrm{g} / \mathrm{ml}$ carbon nanotubes and then exposed to 1 Gy of X-rays are presented in Table I. For the three investigated agents only mercury showed statistically significant increase of DNA damage in comparison to control exposed only to irradiation $(p<0.001)$. These 
TABLE I

Genotoxicity of $\mathrm{Hg}\left(\mathrm{NO}_{3}\right)_{2}$ and nanomaterials in lymphocytes and fibroblasts cell line (evaluated for tail moment parameter - TM).

\begin{tabular}{c|c|c|c|c|c}
\hline \hline \multirow{2}{*}{ Dose } & \multicolumn{2}{|c|}{$\begin{array}{c}\text { Lymphocytes } \\
\text { mercury compound }\end{array}$} & \multicolumn{3}{c}{$\begin{array}{c}\text { Fibroblasts } \\
\text { nanomaterials }\end{array}$} \\
\cline { 2 - 6 } & control & $\mathrm{Hg}\left(\mathrm{NO}_{3}\right)_{2}$ & Control & MWNF & MWNT \\
\hline- & $0.42 \pm 0.13$ & $6.36^{*} \pm 0.25$ & $1.45 \pm 0.08$ & $1.93 \pm 0.16$ & $2.58^{*} \pm 0.36$ \\
1 Gy & $5.45 \pm 1.84$ & $9.82^{*} \pm 0.49$ & $3.57 \pm 0.84$ & $4.22 \pm 0.31$ & $3.48 \pm 0.62$ \\
\hline
\end{tabular}

results suggest that carbon nanotubes do not cause any enhancement of radiation DNA damage.

Comet assay is often used to measure not only DNA lesions but also cellular DNA repair capabilities. Therefore, the last parts of cells were designed to observe the repair processes efficacy of the DNA damage induced by challenging dose of X-rays and to estimate potentially influence biomaterials and chemicals on repair. Figure 2 presents the residual damage levels after exposure to 1 Gy of X-rays evaluated from tail moment parameter in cells without and with pre-treatment with $\mathrm{Hg}\left(\mathrm{NO}_{3}\right)_{2}, \mathrm{MWNT}$ and MWNF. The obtained results show similar repair efficiency as control only in the case of modified carbon nanotubes. On the contrary, the presence of MWNT during repair processes probably entail disorders in radioinduced DNA damage repair, cell division, and other vital functions resulting in the cells death and lack of attached cells. These suggestions are confirmed by Ghosh and Patlolla, who observed negative influence of MWNT on spindle and cell viability $[14,15]$.

Mercury, like heavy metals, is also suspected to cause DNA repair deficiencies [16]. Therefore, in our study we have investigated the effect of mercury on the repair rate of radiation-induced DNA damage in relation to the repair kinetics in the irradiated lymphocytes. The statistical analysis conducted for the irradiated cells with and without mercury pre-incubation has shown an increase in DNA damage levels with the post-irradiation incubation time. These results are consistent with the data obtained by Christie et al. [17] who observed an increase of X-rayinduced (4.5 Gy) DNA damage with the post-irradiation incubation time in $\mathrm{CHO}$ cells treated with $5 \mu \mathrm{M} \mathrm{HgCl}_{2}$ before irradiation. Mercury induced DNA repair deficiency has been postulated to involve the mechanisms based on alteration of DNA repair by mercury interactions with DNA repair enzymes or DNA proteins essential for repair.

\section{Conclusions}

Based on the results, it can be concluded that mercury and non-modified carbon nanotubes have genotoxic effect on cells functions and viability. On the other hand, our research also demonstrated the biocompatibility of modified nanotubes. Moreover, presented preliminary studies indicate that the comet assay test meets the above criteria, which makes it a versatile and potential tool to assess the DNA damage and repair efficiency different compounds and nanomaterials.

\section{Acknowledgments}

The research was performed using equipment purchased in the frame of the project co-funded by the Małopolska Regional Operational Programme Measure 5.1 Krakow Metropolitan Area as an important hub of the European Research Area for 2007-2013, project No. MRPO.05.01.00-12-013/15.

\section{References}

[1] N.P. Singh, M.T. McCoy, R.R. Tice, E.L. Schneider, Exp. Cell Res. 175, 181 (1988).

[2] A. Azqueta, J. Slyskova, S.A. Langie, I. O'Neill Gaivăo, A. Collins, Front Genet. 5, 288 (2014).

[3] C. Gedik, S. Ewen, A. Collins, Int. J. Radiat. Biol. 62, 313 (1992).

[4] R.J. Albertini, D. Anderson, G.R. Douglas, L. Hagmar, K. Hemmiki, F. Merlo, A.T. Natarajan, H. Norppa, D.E.G. Shuker, R. Tice, M.D. Waters, A. Aitio, Mutat. Res. 463, 111 (2000).

[5] O. Ostling, K.J. Johanson, Biochem. Biophys. Res. Commun. 123, 291 (1984).

[6] A. Benko, A. Wiecheć, B. Rajchel, E. Długoń, M. Błażewicz, Acta Phys. Pol. A 129, 174 (2016).

[7] S. Arora, J.M. Rajwade, K.M. Paknikar, Toxicol. Appl. Pharmacol. 258, 151 (2012).

[8] A. Fraczek-Szczypta, E. Menaszek, S. Blazewicz, J. Nanomater. 2011, 1 (2011).

[9] A. Cebulska-Wasilewska, A. Panek, Z. Zabinski, P. Moszczynski, W.W. Au, Mutat. Res. 586, 102 (2005).

[10] A. Cebulska-Wasilewska, I. Pawłyk, A. Panek, A. Wiecheć, I. Kalina, T. Popov, T. Georgieva, P.B. Farmer, Mutat. Res. 620, 145 (2007).

[11] A. Panek, A. Karabin, J. Gębicki, A. CebulskaWasilewska, in: NATO Science for Peace and Security Series E: Human and Societal Dynamics, Vol. 73, IOS Press, 2010, p. 255.

[12] M.V. Williams, T. Winters, K.S. Waddell, Mol. Pharmacol. 31, 200 (1986).

[13] O. Cantoni, M. Costa, Mol. Pharmacol. 24, 84 (1983).

[14] A. Patlolla, B. Knighten, P. Tchounwou, Cells Ethn. Dis. 20, 65 (2010).

[15] M. Ghosh, A. Chakraborty, M. Bandyopadhyay, A. Mukherjee, J. Hazard. Mater. 197, 327 (2011).

[16] M. Asmuss, L.H.F. Mullenders, A. Hartwig, Toxicol. Lett. 112, 227 (2000).

[17] N. Christie, O. Cantoni, M. Sugiyama, F. Cattabeni, M. Costa, Mol. Pharmacol. 24, 173 (1995). 